УДК : 378.6:61-051]:378.091.12:005.963.1

Гончаренко Іван Федорович

заступник начальника Української військово-медичної академії по роботі з особовим складом, аспірант III-го року навчання

ДВНЗ УМО НАПН України, м. Київ, Україна

ganzeros@gmail.com

\title{
ІНФОРМАЦІЙНО-КОМУНІКАЦІЙНІ ТЕХНОЛОГІЇ В ПРОФЕСІЙНІЙ ДІЯЛЬНОСТІ НАУКОВО-ПЕДАГОГІЧНОГО ПРАЦІВНИКА У СФЕРІ ВІЙСЬКОВО-МЕДИЧНОЇ ПІСЛЯДИПЛОМНОЇ ОСВІТИ
}

\begin{abstract}
Анотація. Стаття присвячена місцю і ролі інформаційно-комунікаційних технологій у науковій і педагогічній діяльності науково-педагогічного працівника військово-медичної сфери. Розкрито ставлення науково-педагогічних працівників до використання інформаційно-комунікаційних технологій i засобів навчання у системі підготовки i підвищення кваліфікації у сфері військово-медичної післядипломної освіти. Представлено результати опитування науково-педагогічних працівників щодо використання ІКТ. Виокремлено й узагальнено проблеми сформованості інформаційно-комунікаційної компетентності науково-педагогічного працівника сфери військової медицини в організації і проведенні підвищення кваліфікації, які нині вбачають науково-педагогічні працівники у використанні ІКТ у процесі їх викладацької діяльності.
\end{abstract}

Ключові слова: інформаційно-комунікаційні технології; науково-педагогічний працівник; вища освіта; військово-медична післядипломна освіта; інформаційно-комунікаційна компетентність.

\section{1. ВСТУП}

Постановка проблеми. Сучасна військово-політична обстановка у світі характеризується глибокими змінами, що відбуваються в системі міжнародних відносин як на світовому, так і національному рівнях. Постійне виникнення нових загроз міжнародній безпеці і стабільності потребує, у свою чергу, значної активізації широкого спектру заходів щодо підвищення обороноздатності України і іiі Збройних Сил, забезпечення армії висококваліфікованими фахівцями, спеціалістами у сфері військової медицини зокрема. Усе це вимагає зміни ставлення до підготовки i післядипломної освіти військових медичних кадрів у контексті інтеграційних процесів у світовий і європейський освітній простір.

Серед завдань, що стоять нині перед військовою медичною освітою, такі: створення всебічних умов для неперервного підвищення рівня знань і розширення практичних навичок військових лікарів i провізорів, їх творчого розвитку, саморозвитку й самореалізації; подальша технологізація й інформатизація військової освіти; застосування сучасних освітніх інновацій; інтеграція у європейський і світовий військово-освітній простір; підвищення рівня управління військово-медичною освітою, аналітичного й інформаційного супроводу реалізації проектів і прийнятих рішень тощо.

Невід'ємною складовою сучасного процесу навчання, підготовки і підвищення кваліфікації науково-педагогічних працівників у сфері вищої освіти і військової медичної післядипломної освіти зокрема $\epsilon$ широке застосування інформаційнокомунікаційних технологій. Сучасний навчальний процес неможливий без застосування ресурсів мережі Інтернет, навчальних платформ i засобів IКТ, електронних каталогів і бібліотек, внутрішніх фахових і освітніх електронних мереж, автоматизованих систем управління освітнім процесом тощо. 
Інформаційно-комунікаційні технології (англ. Information and communications technology, ICT), на думку дослідника Н. В. Морзе, це - інформаційні технології на базі персональних комп'ютерів, комп'ютерних мереж і засобів зв'язку, для яких характерна наявність доброзичливого середовища роботи користувача [6]. Інтернет-енциклопедія Вікіпедія визначає ІКТ, як синонім до поняття “інформаційні технології, і підкреслює роль уніфікованих технологій та інтеграцію телекомунікацій (телефонних ліній i бездротових з'єднань), комп'ютерів, програмного забезпечення, накопичувальних i аудіовізуальних систем, які дозволяють користувачам створювати, одержувати доступ, зберігати, передавати та змінювати інформацію й поєднують у собі інформаційні технології, телекомунікації, медіа-трансляції, усі види аудіо і відео обробки, передавання, мережеві функції управління й моніторингу [2].

До сучасних інформаційно-комунікаційних технологій навчання відносять Інтернет-технології, мультимедійні програмні засоби, офісне і спеціалізоване програмне забезпечення, електронні навчальні, навчально-методичні ресурси, системи дистанційного навчання тощо. Серед нових IКТ особливе місце нині відводять “хмарним технологіям" (англ. cloud computing), які пов'язують 3 динамічно масштабованим вільним способом доступу до зовнішніх обчислювальних інформаційних ресурсів у вигляді сервісів, які надаються за допомогою Інтернету (напр., Software as a Service, Platform as a Service). Дослідники В. Ю. Биков, С. О. Семеріков та ін. пов'язують хмарні технології з перспективними напрямами розвитку сучасної освіти у контексті вільного доступу до освітніх ресурсів [1].

Сфера військової медицини, підготовка і післядипломна освіта медичних кадрів, наявність висококваліфікованого психолого-педагогічного персоналу системи післядипломної освіти медичних кадрів потребують кардинального перегляду до ставлення і застосування сучасних ІКТ. Сприяння удосконаленню i реформуванню системи освіти і кадрового забезпечення медичної служби має полягати у модернізації процесу підвищення кваліфікації науково-педагогічних працівників сфери медичної освіти й інтегруванню у цей процес IКТ [10].

Інформаційне суспільство (information society) постає у цих потребах середовищем для створення умов модернізації системи військової медичної освіти і розвитку фахових компетентностей тих, хто іiі здійснює - науково-педагогічних працівників. У даному контексті увагу привертають шляхи розбудови інформаційного суспільства і відповідного середовища у закладах післядипломної медичної освіти і форми застосування інформаційно-комунікаційних технологій у процесі підвищення кваліфікації медичних працівників. Актуальності набуває питання вміння застосовувати психолого-педагогічними працівниками сучасні засоби IКТ і володіння ними інформаційно-комунікаційною компетентністю.

Аналіз останніх досліджень і публікацій. Питання організації безперервного професійного розвитку викладачів у системі медичної освіти відображені у роботах Ю. В. Вороненка, О. П. Мінцера, В. В. Краснова [3]. Обгрунтуванню системи підвищення кваліфікації викладачів вищої військово-медичної освіти присвячені роботи В. В. Солярика, Я. Ф. Радиша, Ф. М. Левченка, А. І. Романенка та ін. На думку вище поданих авторів, система підвищення кваліфікації викладачів вищої школи має складатися 3 двох основних напрямів підготовки: заходи, що проводяться в період повсякденного виконання службових обов'язків, і заходи 3 тимчасовим відривом від робочого місця викладача. До заходів першого напряму відносять: самоосвіту, наставництво, відвідування молодшими викладачами занять досвідчених викладачів, заходи, пов'язані з розробкою і відпрацюванням навчально-методичної документації, участь у командно-штабних навчаннях з викладацьким складом, участь у виконанні науково-дослідних робіт, керівництво науково-практичними роботами студентів. 
Мета статті. За результатами проведених досліджень й опитування психологопедагогічних працівників у системі післядипломної освіти військових медичних кадрів і на фоні загальних стратегій і підходів до питань інформатизації навчального процесу важливим $є$ здійснення аналізу стану й ролі застосування сучасних засобів IКТ психолого-педагогічними працівниками протягом їх науково-педагогічної діяльності у закладах післядипломної медичної освіти, володіння ними інформаційнокомунікаційною компетентністю.

\section{2. РЕЗУЛЬТАТИ ДОСЛІДЖЕННЯ}

Військово-медична освіта є складовою військової і загальнодержавної системи освіти, тому ii функціонування має забезпечувати певне узгодження 3 вимогами Болонської декларації й дотримання укладених у ній принципів і підходів [8; 10]. Реалізація принципів Болонського процесу в освіті нашої держави $є$ не просто рекомендаційною, а обов'язковою для застосування. Оскільки це пов'язано 3 розв'язанням низки проблем і суперечностей, то слід орієнтуватися на усвідомлення необхідності адаптації системи військової освіти України до європейського освітнього простору [5].

Враховуючи положення концепції розвитку військово-медичної освіти і науки, підготовка військово-медичних кадрів для медичної служби Збройних Сил України здійснюється в два етапи: додипломний і післядипломний. Післядипломна освіта i підвищення кваліфікації військових лікарів-спеціалістів (провізорів) здійснюється на ФППК УВМА, а також в Національній медичній академії післядипломної освіти ім. Л. Шупика на циклах тематичного удосконалення (відповідно до Закону України "Про вищу освіту" і наказу Міністра оборони від 21.01.2006 р. № 30 "Про управління системою військової освіти Збройних Сил України"), загальне керівництво системою військової освіти здійснює Департамент військової освіти та науки Міністерства оборони України. Основну діяльність у сфері післядипломної освіти і підвищення кваліфікації військових медичних кадрів здійснюють науково-педагогічні працівники кафедр, що відповідають за підвищення кваліфікації військових лікарів [4; 10].

Питання набуття i розвитку інформаційно-комунікаційної компетентності науково-педагогічними працівниками військово-медичних закладів післядипломної освіти як фахової складової є нині недостатньо вирішеним. Немає чіткої структури і характеристики ІК-компетентності серед основних складових професійної компетентності науково-педагогічних працівників військово-медичної сфери; не визначені основні рівні іiі сформованості; відсутній стандарт, що відповідає основним сучасним тенденціям у галузі післядипломної педагогічної освіти і навчання впродовж життя, не виокремлено і не охарактеризовано інформаційно-комунікаційну складову тощо.

Під час проведення дослідження стану сформованості і застосування IКТ у процесі підвищення кваліфікації кадрів військової медицини ми керувались компетентнісним підходом. Компетентнісний підхід характеризується спрямованістю навчального процесу на формування i розвиток відповідних компетентностей, необхідних людині для повноцінного життя в суспільстві, професійної діяльності, суспільної й особистісної самореалізації. Важливість компетентнісного підходу підкреслюється нині в основних освітніх парадигмах і нормативних документах, а його дотримання потребує особливої уваги фахівців освітньої галузі.

Саме компетентнісний підхід $€$ нині ключовим орієнтиром професійного зростання фахівців медичної сфери, зокрема галузі підвищення кваліфікації i 
безперервного професійного розвитку науково-педагогічних працівників медичної освіти у контексті навчання впродовж життя.

Питанням, пов'язаним 3 виокремленням і трактуванням поняття інформаційнокомунікаційної компетентності, присвячені дослідження В. П. Вембер, А. М. Гуржія, О. Г. Кузьминської, Н. В. Морзе, О. В. Овчарук, О. М. Спіріна, Н. В. Сороко та ін. [7].

У Збірнику наукових праць “Основи стандартизації інформаційно-комунікаційних компетентностей в системі освіти України” зазначено, що ІК-компетентність $\epsilon$ результатом різнобічних здатностей людини і має такі складові:

здатності і вміння:

- здобувати інформацію з різних джерел;

- працювати з різними відомостями;

- критично оцінювати відомості;

- використовувати у професійній діяльності інформаційно-комунікаційні технології;

знання:

- особливостей інформаційних потоків у своїй галузі;

- основ ергономіки й інформаційної безпеки;

- функціональних можливостей ІКТ;

- конкретні навички з використання комп'ютерної техніки та IКТ;

ставлення особистості до застосування ІКТ для відповідальної соціальної взаємодії і поведінки.

Інформаційно-комунікаційна компетентність передбачає здатність людини орієнтуватися в інформаційному просторі, оперувати даними на основі використання сучасних ІКТ відповідно до потреб ринку праці і для ефективного виконання професійних обов'язків. Ця категорія має також включати такі елементи, як ціннісні орієнтації, тобто критичний погляд i критичний аналіз відомостей i даних, що складають зміст, отриманий з різних джерел і за допомогою IКТ (О. В. Овчарук, О. М. Спірін) [7].

Саме тому важливим вбачається 3 урахуванням сучасних тенденцій і вимог до фахових компетентностей (у тому числі й ІК-компетентності) науково-педагогічних працівників вищих навчальних закладів і системи підвищення кваліфікації визначити рівні їх сформованості і проблеми, що стоять перед освітньою системою у цій галузі.

У рамках дослідження щодо визначення ставлення до застосування IКТ і стану сформованості психолого-педагогічної компетентності науково-педагогічних працівників військово-медичної сфери протягом 2012/2013 навчального року було проведено опитування слухачів і викладачів системи післядипломної освіти медичних кадрів. В опитуванні на базі 6-ти закладів взяло участь 132 особи, $40 \%$ яких доктори наук, професори, інші $60 \%$ - кандидати наук, доценти та старші наукові співробітники.

Важливим у опитуванні було 3'ясувати, як респонденти ставляться i чи застосовують інформаційно-комунікаційні технології під час здійснення науковопедагогічної діяльності. Визначення ставлення до IКТ і стану їх застосування відбувалось в рамках загального дослідження рівня фахової компетентності психологопедагогічних працівників сфери військової медичної освіти, що відповідають за підвищення кваліфікації медичних кадрів.

Тому, група питань стосувалась використання інформаційно-комунікаційних технологій (ІКТ). Респондентам було запропоновано обрати такі відповіді: "так”, “ні”, “якщо так, то як часто". За результатами опитування 132 осіб було виявлено, що $87 \%$ опитаних використовують ІКТ, інші - $13 \%$ - не використовують ІКТ у здійсненні фахової діяльності. 
Серед тих, хто використовує ІКТ під час підготовки і проведення занять, індивідуальної роботи зі слухачами, ад’юнктами і докторантами (під час навчання у ад'юнктурі і докторантурі) відповіді розподілились так:

використовую IKT:

- кожного разу для підготовки і проведення навчання і наукових досліджень (31\%); рідко використовую, оскільки це не впиває на ефективність моєї роботи $(8 \%)$;

- рідко використовую, бо недостатньо володію необхідними навичками $(0 \%)$;

- використовую за потреби (87 \%);

- ІКТ потребують значної витрати часу, вважаю не основним у своїй діяльності (8\%).

Сума відсотків у даному питанні не становить $100 \%$, оскільки респонденти не вибирали лише один варіант відповіді, а зазначали один або декілька пунктів.

Слід підкреслити, що ці відповіді дозволили виявити тенденцію ставлення респондентів до ролі й місця інформаційно-комунікаційних технологій у їх науковопедагогічній діяльності, а саме: потребу у використанні ІКТ усвідомлює і використовує (за потреби) переважна частина професорсько-викладацького складу у системі підвищення кваліфікації медичних кадрів, однак, частина респондентів вважає, що оволодіння інструментами ІКТ, їх підготовка і застосування в процесі підвищення кваліфікації потребують значної витрати часу.

Частково це можна пояснити тим, що значна кількість опитаних ознайомились 3 інструментами ІКТ у процесі здійснення фахової діяльності, їх основна вікова категорія підлягає періоду, коли не здійснювалось навчання у ВНЗ з питань застосування ІКТ, натомість інша частина активно застосовує ІКТ. Цю тенденцію доводить й віковий розподіл опитаних фахівців, де у переважній кількості з тих, хто звертається до засобів IКТ, - респонденти до 50-річного віку.

Відповіді респондентів свідчать, що існує розрізненість ставлення до ролі IКТ у системі підвищення кваліфікації медичних працівників.

Запитання щодо ставлення до ролі ІКТ стосувалось того, які саме IКT застосовують респонденти у своїй навчально-педагогічній діяльності. Відповіді розподілились так:

- користуюсь ресурсами електронних бібліотек, каталогів, сайтами університетів тощо (87 \%);

- створюю навчально-методичні матеріали засобами IКТ, використовуючи програми Power Point, Word, Excell (86\%);

- веду дистанційні курси, вебінари (15\%);

- створюю електронні тести, електронні щоденники успішності слухачів тощо $(30 \%)$;

- маю свій електронний щоденник (2\%), веб-сторінку (2 \%), блог (0 \%).

Загальна картина проведеного опитування засвідчила, що частина респондентів недостатньо обізнана зі спектром IКТ, що може бути застосований під час процесу підвищення кваліфікації медичних кадрів і підготовки до занять.

Проведене опитування дозволило узагальнити й виокремити проблеми у сформованості інформаційно-комунікаційної компетентності науково-педагогічного працівника сфери військової медицини у контексті проблем сформованості їх фахової компетентності, що подані у табл. 1. Ми відносимо їх до т. зв. діяльнісно-рефлексивної складової психолого-педагогічної компетентності вищезазначених фахівців. Слід зазначити, що ці проблеми були виокремлено під час опитування самими респондентами. 
Табличя 1

\section{Проблеми сформованості інформаційно-комунікаційної компетентності науково-педагогічного працівника сфери військової медицини}

\begin{tabular}{|c|c|}
\hline $\begin{array}{c}\text { Складова } \\
\text { психолого- } \\
\text { педагогічної } \\
\text { компетентності }\end{array}$ & Проблема, яку виокремили респонденти \\
\hline $\begin{array}{c}\text { Діяльнісно- } \\
\text { рефлексивна } \\
\text { складова }\end{array}$ & 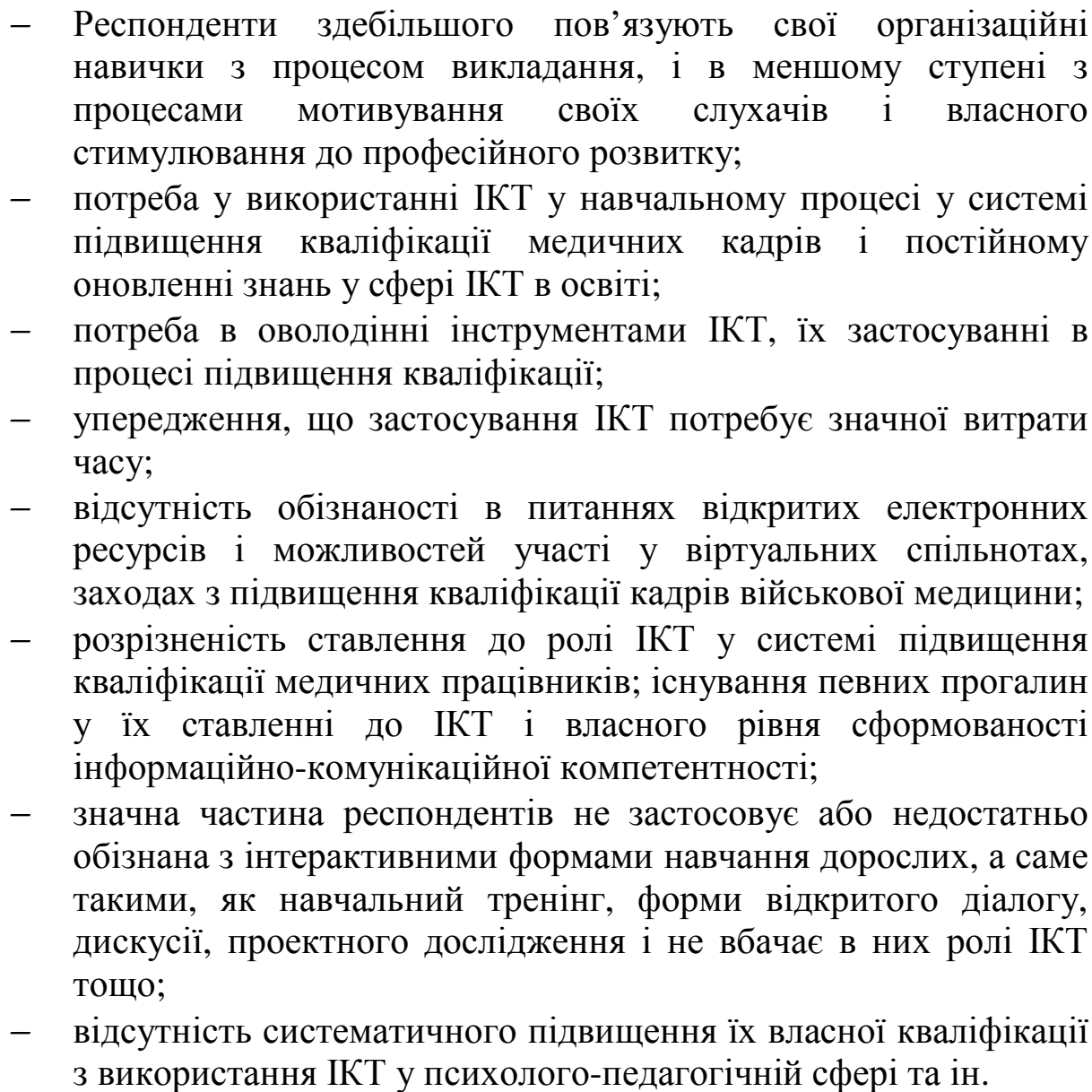 \\
\hline
\end{tabular}

Слід підкреслити, що переважна більшість респондентів застосовують сучасні інформаційно-комунікаційні технології для підготовки і проведення занять, створюють власні електронні ресурси, які демонструють на заняттях. Не досить значна кількість респондентів ведуть електронні щоденники, власні блоги і мають електронну сторінку, що свідчить про існування певних прогалин у їх ставленні до IКТ і рівня сформованості інформаційно-комунікаційної компетентності.

Проведене опитування підтвердило необхідність подальшого вивчення ставлення до застосування IКТ і сформованості інформаційно-комунікаційної компетентності сучасних науково-педагогічних працівників військово-медичної сфери.

Важливим фактором у контексті розвитку професіоналізму психологопедагогічних кадрів $\epsilon$ те, що післядипломна освіта покликана виконувати інформаційну функцію, а саме - сприяння формуванню інформаційної культури фахівців і розвитку вмінь роботи в інформаційному просторі.

В арсеналі застосування ІКТ психолого-педагогічними працівниками сфери військової медичної освіти, у тому числі й підвищення кваліфікації, мають бути дистанційні форми навчання, де значну частку становлять самостійні форми роботи, 
так звані кейс-технології, різноманітні форми мережевої взаємодії між викладачами і слухачами тощо. Це дасть змогу забезпечити безперервність професійного й особистісного розвитку кадрів військової медичної сфери, обмін досвідом 3 професійної діяльності, сприятиме здійсненню наукових досліджень, забезпечить підтримку інновацій у військовій медичній галузі.

На думку сучасного вченого В. В. Олійника, на часі є застосування дистанційних форм підвищення кваліфікації як інноваційних, що забезпечують широкий доступ особистості до кращих світових освітніх ресурсів і самонавчання найбільш доступним способом, отримання професійно-орієнтованої й особистісно-значущої інформації упродовж усього життя. Наразі програми кваліфікаційних курсів, що здійснюються дистанційними засобами із застосуванням ІКТ, на думку дослідника, мають бути як підсумкового, так і прогностичного типу і враховувати специфіку особистісного розвитку фахівця [9].

На думку В. В. Олійника, поєднання дистанційних форм підвищення кваліфікації 3 традиційними дозволяє розв’язати суттєве протиріччя між обсягом знань і лімітом навчального часу без збільшення тривалості відриву слухачів від виконання професійних обов'язків; оптимально використати переваги очного (з відривом від виробництва) і дистанційного навчання з використанням сучасних IКТ (без відриву від виробництва); підвищити рівень і якість застосування у навчанні IКТ та Інтернеттехнологій i, на цій основі, поліпшити інформаційну підготовку слухачів; забезпечити новий, достатньо високий рівень самостійної роботи слухачів як за рахунок збільшення часу на виконання атестаційних робіт і поліпшення наукового керівництва, так і через підвищення вимог до їх якості і більш контрольованої процедури захисту [9].

\section{3. ВИСНОВКИ ТА ПЕРСПЕКТИВИ ПОДАЛЬШИХ ДОСЛІЖЕНЬ}

Сучасна практика підвищення кваліфікації військово-медичних кадрів психологопедагогічними працівниками системи післядипломної медичної освіти свідчить про недостатне використання у даному процесі IKT й обмеження у можливостях підвищення власної кваліфікації з питань використання ІКТ, недостатнє володіння інформаційно-комунікаційною компетентністю. Переважно застосування IКТ відбувається для розв'язання практичних завдань поточних занять 3 підвищення кваліфікації фахівців. Натомість роль ІКТ в інтегруванні фахівців до професійних спільнот з обміну досвідом (у тому числі й міжнародних), здійснення самопідготовки і професійного розвитку недостатньо усвідомлюється зазначеною фаховою спільнотою.

Аналіз сучасного стану застосування сучасних засобів ІКТ і визначення їх ролі психолого-педагогічними працівниками під час здійснення науково-педагогічної діяльності у закладах післядипломної медичної освіти, стан володіння ними інформаційно-комунікаційною компетентністю дозволяе окреслити перспективи подальших розвідок із зазначеної проблеми. Особливої уваги дослідників потребують механізми і шляхи створення можливостей для підвищення кваліфікації науковопедагогічних працівників сфери військової медичної освіти у застосуванні IКТ, зокрема хмарних технологій, їх навчально-методична підтримка. Існує потреба оновлення програм підвищення кваліфікації фахівців військово-медичної сфери, насичення їх елементами доцільного застосування IКТ, використання потенціалу вітчизняних i міжнародних спільнот і мереж, що сприяє інтегруванню сучасної військової медичної освіти у світовий освітній простір у контексті навчання впродовж життя. 


\title{
СПИСОК ВИКОРИСТАНИХ ДЖЕРЕЛ
}

1. Биков В. Ю. Моделі організаційних систем відкритої освіти : монографія. - К. : Атіка, 2008. $684 \mathrm{c}$.

2. Вікіпедія - вільна енциклопедія [Електронний ресурс]. - Режим доступу : http://uk.wikipedia.org/.

3. Вороненко Ю. В., Мінцер О. П., Краснов В. В. Організація безперервного професійного розвитку викладачів у системі медичної освіти (аналітичний огляд та пропозиції) // Медична освіта, - № 4. 2012. - C. 6-17.

4. Білий В. Я., Пасько В. В., Солярик В. В. Новий ступінь розвитку системи військово-медичної освіти // Проблеми військової охорони здоров'я і шляхи їі реформування (військово-медична освіта та наука в Україні) : зб. наук. праць. - К. : УВМА, 1998. - С. 19-25.

5. Модернізація вищої освіти України і Болонський процес / [уклад.: М. Ф. Степко, Я. Я. Болюбаш, К. М. Левківський та ін. ; відп. ред. М. Ф. Степко]. - К. : Мін-во освіти і науки України, 2004. - 24 c.

6. Морзе Н. В. Основи методичної підготовки вчителя інформатики : монографія. - К.: Курс, 2003. $372 \mathrm{c.}$

7. Основи стандартизації інформаційно-комунікаційних компетентностей в системі освіти України: метод. рекомендації/ / [В. Ю. Биков, О. В. Білоус, Ю. М. Богачков та ін..]; за заг. ред. В .Ю. Бикова, О. М. Спіріна, О. В. Овчарук. - К. : Атіка, 2010. - 88 с.

8. Пасько В. В. Національна система військово-медичної освіти в Україні // Медична освіта. - 2000. № 1. - С. 55-60.

9. Підвищення кваліфікації керівників освіти за дистанційною формою навчання / [Олійник В. В., Биков В. Ю., Гравіт В. О. та ін.]; за заг. ред. В. В. Олійника, - К. : Логос, 2006. - 408 с.

10. Програма розвитку системи медичного забезпечення Збройних Сил України на 2006-2011 роки. К. : ДОЗ, 2006. - 23 с.

Матеріал надійшов до редакиіï 31.07 .2014 p.

\section{ИНФОРМАЦИОННО-КОММУНИКАЦИОННЫЕ ТЕХНОЛОГИИ В ПРОФЕССИОНАЛЬНОЙ ДЕЯТЕЛЬНОСТИ НАУЧНО-ПЕДАГОГИЧЕСКОГО РАБОТНИКА В СФЕРЕ ВОЕННО-МЕДИЦИНСКОГО ПОСЛЕДИПЛОМНОГО ОБРАЗОВАНИЯ}

\author{
Гончаренко Иван Фёдорович \\ аспирант III-го года обучения \\ ГВУЗ УМО НАПН Украины, г. Киев, Украина \\ ganzeros@gmail.com
}

заместитель начальника Украинской военно-медицинской академии по работе с личным составом,

Аннотация. Статья посвящена месту и роли информационно-коммуникационных технологий в реализации в научной и педагогической деятельности работника военномедицинской сферы. Раскрыто отношение научно-педагогических работников к использованию информационно-коммуникационных технологий и средств обучения в системе подготовки и повышения квалификации в сфере военно-медицинского последипломного образования. Представлены результаты опроса научно-педагогических работников по использованию ИКТ. Выделены и обобщены проблемы сформированности информационно-коммуникационной компетентности научно-педагогического работника сферы военной медицины в организации и проведении повышения квалификации, которые они выделяют при использовании ИКТ в процессе преподавательской деятельности.

Ключевые слова: информационно-коммуникационные технологии; научнопедагогический работник; высшее образование; военно-медицинское последипломное образование; информационно-коммуникационная компетентность. 


\title{
INFORMATION AND COMMUNICATION TECHNOLOGIES IN PROFESSIONAL ACTIVITY OF SCIENTIFIC AND EDUCATIONAL PERSONNEL IN THE SPHERE OF POST DIPLOMA MILITARY MEDECINE EDUCATION
}

\author{
Ivan F. Honcharenko \\ Deputy Head of Ukrainian Military Medicine Academy for human resources' activity \\ PhD student \\ Universityof Management in Education of NAPS of Ukraine, Kyiv, Ukraine \\ ganzeros@gmail.com
}

\begin{abstract}
The article deals with the place and the role of information and communication technologies in the scientific and pedagogical activity of pedagogical personnel in the sphere of post diploma military medicine education. The results of the questionnaire for the above mentioned personnel are presented in the article. There are emphasized and generalized the problems of information and communication competence formation of scientific and educational personnel in the sphere of post diploma military medicine using ICT in their teaching activities in the process of post-diploma education.
\end{abstract}

Keywords: information and communication technologies; scientific and pedagogical personnel; higher education; post diploma military medicine education; informational and communicational competence.

\section{REFERENCES (TRANSLATED AND TRANSLITERATED)}

1. Bykov V. Y. Models of the open education organizational models : monograph. - K. : Atiка, 2008. - 684 p. (in Ukrainian)

2. Wikipedia [online]. - Available from : http://uk.wikipedia.org/. (in Ukrainian)

3. Voronenko Y. V., Micner O. P., Krasnov V. V. Organisation of lifelong professional learning of perofessors in the system of medical education (analytical review and proposals) / Y. V. Voronenko, O. P. Micner, V. V. Krasnov // Medical education, - \# 4. - 2012. - P. 6-17. (in Ukrainian)

4. Bilyj V. J., Pasko V. V., Solaryk V. V. New development stage of the system of military medical education // Problems of military heals saving and the ways of reformation (military medical education and science in Ukraine): scientific.rev. - Kyiv : UVMA, 1998. - P. 19-25. (in Ukrainian)

5. Higher education modernization and Bolognia process / Comp.: M. F. Stepko, J. J. Bolubash, K .M. Levkivskyj oth.; Ed.Ch. M. F. Stepko. - K. : MOES of Ukraine, 2004. - 24 p. (in Ukrainian)

6. Morze N. V. The Basics of the methodological training of informatics teachers : Monograph. - K. : Kurs, 2003. - 372 p. (in Ukrainian)

7. The basics of standardization of informational and communicational competencies in the Ukrainian system of education: method. Recommendations / [V. Y. Bykov, O. V. Bilous, Y. M. Bogachkov oth.]; ed.ch. ред. V. Y. Вykov, О. М. Spirin, О. V. Ovcharuk. - К.: Atika, 2010. - 88 p. (in Ukrainian)

8. Pasko V. V. National system of military medical education in Ukraine // Medical education. - 2000. - \# 1. - P. 55-60. (in Ukrainian)

9. Education managers in-service training by distance learning form of education / [Olijnyk V. V., Bykov V. Y., Gravit V. O. oth.]; Ed.ch. V. V. Olijnyk. - K. : Logos, 2006. - 408 p. (in Ukrainian)

10. The Programme of medical fulfillment system development of Military Force of Ukraine for $2006-2011$ years. - K. : DOZ, 2006. - 23 p. (in Ukrainian) 